tutu (profesorowie M. Bachvarov, E. Dziegieć, S. Liszewski), organizację w 2006 r. Międzynarodowej Konferencji ATLAS w Lodzi. Wcześniej Zakład i Katedra, a obecnie Instytut utrzymywał w różnych okresach współpracę naukową i dydaktyczną z ośrodkami naukowymi we Francji (Angers, Aix-en-Provence), na Słowacji (Preszów, Bańska Bystrzyca) oraz z Uniwersytetem w Giessen (Niemcy), Joeansu (Finlandia), Nijmegen (Holandia), Saloniki (Grecja), Sofia (Bułgaria), Tbilisi (Gruzja), Petersburg (Rosja), Praga (Czechy).

Więcej informacji na temat działalności łódzkiego ośrodka geografii turyzmu można znaleźć w obszernym opracowaniu S. Liszewskiego zamieszczonym w Turyzmie, t. 16, z. 2 (2006), s. 153182 oraz na stronie internetowej www.turyzm.edu.pl.

Stanistaw Liszewski

\section{Geografia turyzmu w Uniwersytecie \\ im. Adama Mickiewicza w Poznaniu Centrum Turystyki i Rekreacji}

Badania dotyczące turystyki i wypoczynku mają na Wydziale Nauk Geograficznych i Geologicznych Uniwersytetu im. A. Mickiewicza ponad czterdziestoletnią tradycję. Ich prekursorem był. prof. dr hab. T. Bartkowski, natomiast kontynuatorami prof. dr hab. A. Marsz, prof. dr hab. D. Sołowiej oraz prof. dr hab. E. Biderman. W 2000 r. powołano na Wydziale Nauk Geograficznych i Geologicznych Centrum Turystyki i Rekreacji, którego kierownikiem jest prof. dr hab. Zygmunt Młynarczyk. Zespół badaczy Centrum tworzą zarówno geografowie, jak i specjaliści z zakresu ochrony środowiska przyrodniczego oraz turystyki i rekreacji.

Działalność dydaktyczna Centrum obejmuje prowadzenie od 2000 r. interdyscyplinarnego kierunku studiów turystyka i rekreacja - w trybie stacjonarnym i niestacjonarnym na studiach pierwszego $\mathrm{i}$ drugiego stopnia. Wydział współpracuje z wieloma europejskimi uniwersytetami i uczelniami wyższymi w ramach programu Socrates-Erasmus.

Badania naukowe skoncentrowane są wokół zagadnień związanych z przestrzenią wykorzystywaną przez człowieka w czasie wolnym. Problematyka badawcza obejmuje analizę interakcji, jakie zachodzą między przyrodą, turystyką i gospodarką. Poszukuje się nowych rozwiązań metodycznych dotyczących oceny potencjału turystycznego, umożliwiających przejście od diagnozy walorów śro- and currently the institute have maintained cooperation with academic centres in France (Angers, Aix-en-Provence) and Slovakia (Prešov, Bańska Bystrica) and with universities in Giessen (Germany), Joensuu (Finland), Nijmegen (the Netherlands), Thessaloniki (Greece), Sofia (Bulgaria), Tbilisi (Georgia), St Petersburg (Russia) and Prague (Czech Republic).

Details on the activity of the Łódź tourism geography centre can be found in an article by Liszewski, published in Turyzm, vol. 16, issue 2 (2006), pp. 153-182.

Stanisław Liszewski

\section{Geography of tourism at the Adam Mickiewicz University in Poznań \\ The Tourism and Leisure Centre}

Research concerning tourism and leisure at the Department of Geological and Geographical Sciences at Adam Mickiewicz University has a more than forty-year tradition. Prof. dr hab. Bartkowski was the precursor of studies continued by Prof. dr hab. Marsz, Prof. dr hab. Solowiej and Prof. $\mathrm{dr}$ hab. Biderman. The Tourism and Leisure Centre, whose head is Prof. dr hab. Mlynarczyk, was created at the Geological and Geographical Sciences Department in 2000. The research team of this centre consists of geographers as well as specialists dealing with the protection of the natural environment and tourism and leisure.

Teaching activity at the centre includes the interdisciplinary subject of Tourism and leisure' including regular and extramural Licencjat and also Master's degrees. The department cooperates with other European universities and academies within the Socrates-Erasmus programme.

Academic research focuses on spatial issues resulting from the use of 'free time'. Research issues analysing interactions between nature, tourism and management, and new methodological approaches concerning tourism potential are being looked at. Such methods would make possible a move from a diagnosis of the advantages of the natural environment to the development of a strategy for its use in 
dowiska przyrodniczego do strategii jego wykorzystania poprzez zagospodarowanie turystyczno-rekreacyjne. Kolejnym ważnym zadaniem jest rozpoznanie uwarunkowań i możliwości aktywizacji turystyki osób niepełnosprawnych. W celu porozumiewania się z grupa turystów niesłyszących opracowano Multimedialny podręcznik do nauki języka migowego dla potrzeb turystyki i rekreacji (2003 r.).

Do aktualnie realizowanych w Centrum projektów badawczych należą: „Narciarstwo wodne” praca pod kierunkiem prof. dr hab. Zygmunta Młynarczyka; „Wpływ wyciaggów narciarskich nart wodnych na dotlenienie jezior i atrakcyjność turystyczną na przykładzie jeziora Necko w Augustowie” - mgr Krzysztof Piotrowski; ,Zróżnicowanie przestrzeni turystycznej rynien jezior kórnicko-zaniemyskich i jezior pszczewskich" - mgr I. Potoc$\mathrm{ka}$, ,Aktywizacja rozwoju turystyki w dolinie Obry” - mgr A. Przybylska, ,Turystyka osób niesłyszących i możliwości jej aktywizacji poprzez zastosowanie multimedialnego systemu informacji turystycznej” - dr Alina Zajadacz, „Uwarunkowania i plany rozwoju turystyki" - praca zbiorowa pod redakcja prof. dr hab. Zygmunta Młynarczyka i dr Aliny Zajadacz.

W roku 2008 planowane jest powołanie branżowego czasopisma naukowego „Turystyka”, które będzie forum interdyscyplinarnych dyskusji przedstawicieli różnych dyscyplin naukowych zaangażowanych $\mathrm{w}$ badania nad turystyka.

Alina Zajadacz

\section{Geografia turyzmu w Uniwersytecie Gdańskim Instytut Geografii}

Działalność naukowo-badawcza i dydaktyczna z zakresu geografii turyzmu w Instytucie Geografii (powołanym w 2005 r.) skoncentrowana jest w istniejących dwóch katedrach o profilu ekonomicznym: Katedrze Geografii Ekonomicznej (KGE) i Katedrze Rozwoju Regionalnego (KRR), a także w Katedrze Geografii Fizycznej i Ksztaltowania Środowiska.

W ramach działalności podstawowej związanej z kształceniem studentów na studiach magisterskich dziennych i zaocznych, licencjackich i magisterskich uzupełniających były prowadzone zajęcia w formie wykładów i ćwiczeń z geografii turystyki, nadmorskich regionów turystycznych tourism and recreation management. Another important task is to recognize the conditions and opportunities for developing tourism for disabled people. A multimedia handbook on sign language was developed in 2003 for the needs of tourism and leisure professionals to communicate with groups of deaf tourists.

The following research projects are undertaken in the Tourism and Leisure Centre: 'Water skiing' - managed by Prof. dr hab. Zygmunt Mynarczyk; The influence of water skiing on lake oxidation and tourist attractiveness: the example of Necko Lake in Augustów (north-eastern Poland)' - Krzysztof Piotrowski M.Sc.; 'Differentiation of tourism spaces: Kórnik-Zaniemyśl and Pszczew Lakes' - Ilona Potocka M.Sc.; 'The activation of tourism development in the Obra river valley' - Anna Przybylska M.Sc.; 'The tourism of the deaf and opportunities activation using a tourist information multimedia system' - Dr Alina Zajadacz; 'Conditions and development plans for tourism' - collective research coordinated by Prof. dr hab. Zygmunt Młynarczyk \& Dr Alina Zajadacz.

In 2008, there are plans to create an academic journal 'Tourism', which would be a forum for interdisciplinary discussion for specialists representing the various disciplines involved in tourism and leisure studies.

Alina Zajadacz

\section{Geography of tourism at the University of Gdańsk Institute of Geography}

The academic, research and teaching activity of the Institute of Geography (which was established in 2005) in the field of tourism geography occurs in two existing departments with an economic basis (the Department of Economic Geography and the Department of Regional Development), and also in the Department of Physical Geography and Environmental Development.

The basic activity related to teaching regular and extramural students of Licencjat and Master's university programmes includes lectures and classes on the geography of tourism, coastal tourism regions and agro-tourism; Master's and Licencjat seminars; and local and regional fieldwork. Such subjects as tourism marketing and 